UDC 347.9

Mr Savo Teofilović

predsednik Okružnog suda u Novom Sadu u penziji

\title{
ULOGA I ZADACI NOSILACA PRAVOSUDNIH FUNKCIJA NA OSTVARIVANJU ZAKONITOSTI*
}

Uloga i zadaci nosilaca pravosudnih funkcija određeni su Ustavom i zakonima, a to su zaštita slobode i prava građana, zakonom utvrđena prava i interesi pravnih subjekata i obezbeđenje zakonitosti. Ta njihova dužnost nije samo formalistička, istrgnuta iz društvene sredine u kojoj se ostvaruje, već se zasniva na načelima društveno-političkog sistema u kome se obavlja ta funkcija. Stoga, zadatak sudija nije samo da se u suđenju drže slova pojedine pravne norme, već sadržinu i smisao pravne norme moraju tražiti u razumevanju celokupnog ustavnog i pravnog poretka, a moraju uzimati u obzir i načela na kojima počivaju pravne norme.

U obavljanju sudske funkcije osnovno načelo pravičnosti nije samo apstraktna filozofska norma bez osnova u životnoj stvarnosti. Pravično je ono što se zasniva na poštovanju i razvijanju ljudske ličnosti, zbližavanju ljudi, težnji za ostvarivanjem sve bogatije kulture i civilizacije našeg društva, poštovanju slobode i ravnopravnosti pojedinaca i pravnih subjekata, sprečavanju bilo kakvih iskorišćavanja čoveka itd.

Da bi sudija mogao uspešno izvršiti svoju časnu i odgovornu funkciju mora biti obrazovan ne samo kao dobar stručnjak, već i kao moralan čovek, jer je to preduslov za objektivnu i zakonitu primenu zakona. Sudija mora biti osnov zakonitosti i pravde u društvu. Još je u rimskom pravu istaknuto da ,pravda treba da bude slobodna, jer nema ništa gore od podmitljive pravde, potpuna, jer ne sme da šepa, i brza, jer je sporost u neku ruku negacija pravde".

U svome radu sudija se mora strogo pridržavati zakona i kodeksa svoje struke. To proizilazi i iz člana 1 . i 2 . Kodeksa ponašanja lica odgovornih za primenu zakona, usvojenog rezolucijom Generalne skupštine

* Rad primljen: 25. IV 2007. godine. 
Ujedinjenih nacija broj 34/169. od 17. decembra 1979. godine u kojoj se kaže: „Lica odgovorna za primenu zakona moraju uvek obavljati zadatak koji im nameće zakon tako što će služiti zajednici i štititi sva lica od nezakonitih postupanja u skladu sa visokim stepenom odgovornosti koje njihova profesija zahteva."

U skladu sa ovim opštim principima, sudije se u svome radu moraju pridržavati sledećih načela:

Strogo moraju čuvati svoju nezavisnost i ne dozvoliti nikakvo mešanje u svoj rad, koje bi moglo da ugrozi nezavisno obavljanje funkcije. Time će onemogućiti zloupotrebu vlasti i prava, jer upravo sudije moraju biti nosioci pravnih načela, a ne sprovodioci privilegovanih interesa.

Moraju čuvati ugled suda. Cuvanje ugleda suda moraju zahtevati i od svih ostalih učesnika sa kojima dolaze u kontakt prilikom vršenja sudijske funkcije.

Čuvanju ugleda suda moraju doprinositi i primernim vladanjem kako u sudu, tako i izvan suda, zatim zahtevom da se i drugi učesnici u postupku primerno vladaju u sudu, svojom primernom spoljašnošću, čuvanjem reda, tačnošću, ažurnošću u radu, poštovanjem radnog vremena i radne discipline, kao i drugim odgovarajućim merama, a posebno ne primanjem poklona ili usluge u vezi sa svojim radom.

Sudije moraju posebnu pažnju pokloniti brzini postupaka koje vode, naročito krivičnog postupka. Samo brz postupak je efikasan i zakonit postupak. Brz postupak je u interesu oštećenog, žrtve krivičnog dela, posebno ako je sudska odluka osnov za ostvarenje naknade štete ili otklanjanje, odnosno smanjenje posledica krivičnog dela. Objektivno posmatrano, brzo sproveden i završen postupak je u interesu i samog okrivljenog, kad se na to gleda sa stanovišta mogućih pravnih posledica, koje su povezane sa krivičnim postupkom, a i sa čisto psihološkog aspekta.

Sudije među sobom, kao i prema radnoj zajednici, moraju imati i razvijati korektne odnose. Na taj način će doprineti stvaranju atmosfere koja omogućava uspešnije obavljanje funkcije i delovanje suda kao celine.

Isto tako moraju imati korektne odnose prema javnom tužiocu, javnom pravobraniocu, advokatima i drugim strankama i njihovim punomoćnicima. Takvim odnosom će stvoriti uslove za stvaralački rad.

Radi što savesnijeg ispunjavanja svoje društvene funkcije sudije su dužne da usavršavaju svoje znanje. Moraju biti svesni da će svojim stručnim znanjem, koje stalno usavršavaju, moći izvršiti zadatke koje im je društvo postavilo. Stoga, zanemarivanje stručnog usavršavanja znači zanemarivanje izvršavanja sudijske funkcije.

Navedene ciljeve će postići i svojim ličnim zalaganjem, brižljivim pripremanjem procesnih radnji, produbljenim stručnim studiranjem i detaljnim proučavanjem činjeničnog i pravnog stanja, tako da se bez potrebe ne odugovlači sa postupkom, niti će to dozvoliti drugim učesnicima u postupku, vodeći računa o rokovima postupka, sudskom poslovniku i zaključcima sudskog veća. 
Sudske odluke moraju biti razumljive, formulacije jasne i pravilno literarno obrađene, a pisane lepim srpskim književnim jezikom.

Pisani otpravci odluka moraju se izraditi u zakonom određenim rokovima, bili oni prekluzivne ili samo instruktivne prirode. Neopravdanim prekoračenjem tih rokova sudije krše zakon i sudski poslovnik i moraju biti pozvani na odgovornost.

Strogo moraju poštovati načela službene tajne u meri koju tu obavezu nalažu procesne norme.

Časna je i odgovorna dužnost svakog sudije da se iznetih načela drži u svakodnevnom radu, da ih razvija i obogaćuje i da svojim ličnim primerom upućuje i druge na isto takvo ostvarivanje navedenih načela.

$\mathrm{Da}$ bi sudovi kao institucije i sudije kao nosioci funkcija mogli ostvariti svoje zadatke i udovoljiti zahtevima našeg društva i vremena u kome živimo, u borbi protiv kriminala i svih drugih društveno negativnih pojava, neophodno je da nadležni državni organi preduzmu efikasne mere za otklanjanje teškoća i problema u radu sudova (na zadovoljavajući način rešiti im kadrovske, materijalne i druge neophodne uslove za rad). $\mathrm{Na}$ taj način će se otkloniti slabosti koje proizilaze iz ovih teškoća, bilo da su one objektivne ili subjektivne prirode. Istovremeno će sudije moći još efikasnije doprinositi ostvarivanju zakonitosti kao neophodnom preduslovu za prevazilaženje opšte društvene krize i funkcionisanju pravne države.

Uspostavljanje pravne države predstavlja realnost samo ako je shvatimo kao zajednički zadatak svih nas, a posebno sudija kao nosilaca pravosudnih funkcija. Pravna država se ne može uspostaviti na privilegijama i nemoralnosti. Monteskje u Duhu zakona kaže: „Moral se ne može urediti zakonima, jer zakonom je lako urediti ono što se duguje drugima, ali je teško obuhvatiti sve ono što čovek duguje samom sebi." Pravna država je naš opšti interes i naš dug prema ovom narodu i našem potomstvu.

Nema pravne države bez zakonitosti i pravednosti u radu sudija prilikom primene prava. Biti sudija mora postati najveća intelektualna i stručna ,privilegija” ostvarljiva samo vrednim, moralnim i časnim stručno osposobljenim pravnicima. Stari grčki filozof je rekao da dobar sudija može biti samo dobar čovek. „Dobrota” sudije je u pravednosti, a ne u predusretljivosti, jer njihove odluke moraju biti realne, razumne, pravične i celishodne. Zato sudije ne smeju da zaborave misao Viktora Igoa da „nije teško biti dobar, teško je biti pravedan” i propis iz Dušanovog zakonika „da sudije sude samo po zakonu”. 